\title{
Colorectal cancer screening: Video-reviewed flexible sigmoidoscopy by nurse endoscopists - A Canadian community-based perspective
}

\author{
TF Shapero MD FRCPC ${ }^{1}$, PE Alexander BA ${ }^{2}$, J Hoover RN ${ }^{1}$, E Burgis RN ${ }^{1}$, \\ R Schabas MHSc MD FRCPC ${ }^{3}$
}

TF Shapero, PE Alexander, J Hoover, E Burgis, R Schabas. Colorectal cancer screening: Video-reviewed flexible sigmoidoscopy by nurse endoscopists - A Canadian communitybased perspective. Can J Gastroenterol 2001;15(7):441-445.

BACKGROUND: Colorectal cancer (CRC) is the third most common incident cancer and the second most fatal cancer in Canada. Flexible sigmoidoscopy (FS) is one of the modalities under consideration for CRC screening. The present series reports on a screening program of FS performed by nonphysician endoscopists in a Canadian community setting, with video review of procedures by physicians and recommendation of follow-up colonoscopy where polyps are identified.

RESULTS: Five hundred twenty-five, average-risk, asymptomatic patients were examined. After exclusion of inappropriate referrals, 488 remained for analysis. The duration and extent of examination were comparable with those of previous studies elsewhere. Compliance with suggested follow-up was $97.3 \%$. Polyps were identified at FS in $15.4 \%$ of examinees. In $8.2 \%$ of patients, the polyps were neoplastic at subsequent histology. Four malignant lesions were detected, all at an early stage. There were no complications of FS.
INTERPRETATION: This report shows that FS can be carried out safely and effectively by nonphysician personnel in a community setting in Canada. The manpower cost for nonphysician operators is considerably less than that for specialist physician endoscopists. This approach deserves consideration in cost effectiveness analyses of CRC screening.

Key Words: Adenoma; Colorectal cancer; Flexible sigmoidoscopy; Gastrointestinal assistant; Neoplastic; Nurse-performed; Polyp

Dépistage du cancer colorectal sigmoïdoscopie à l'aide d'un fibroscope souple, effectuée par des endoscopistes infirmiers et revue sur vidéo : expérience en milieu communautaire au Canada

CONTEXTE : Le cancer colorectal (CCR) constitue le troisième type de cancer ayant la plus forte incidence et le deuxième entraînant la plus forte mortalité au Canada. La sigmoïdoscopie à l'aide d'un fibroscope souple (FS) est l'un des moyens envisagés pour le dépistage de ce type de

voir page suivante

${ }^{1}$ Scarborough Hospital, General Division, Endoscopy Unit; ${ }^{2}$ Department of Public Health Sciences, Faculty of Medicine, University of Toronto;

${ }^{3}$ Cancer Care Ontario, Preventive Oncology, Toronto, Ontario

Correspondence and reprints: Dr Ted Shapero, 3030 Lawrence Avenue East, Suite 214, Scarborough, Ontario M1P 2T7.

Telephone 416-438-5755, fax 416-438-3324, e-mail 5shaps@sympatico.ca

Received for publication November 3, 2000. Accepted April 9, 2001 
cancer. La présente série fait état d'un programme de dépistage du CCR par FS, mis en œuvre par des endoscopistes non médicaux dans une communauté au Canada; les examens sont revus sur vidéo par des médecins et des recommandations sur les coloscopies de suivi sont formulées dans les cas où sont décelés des polypes.

RÉSULTATS : Cinq cent vingt-cinq patients à risque moyen, ne présentant aucun symptôme ont été examinés; de ce nombre, 488 ont été retenus aux fins d'analyse après exclusion des cas jugés non pertinents. La durée et l'étendue de l'examen étaient comparables à celles d'études antérieures menées ailleurs. Les recommandations quant au suivi ont été respectées dans une proportion de 97,3\%. Des polypes ont été décelés au
FS chez 15,4 \% des patients et se sont révélés néoplasiques à l'examen histologique chez 8,2 \% d'entre eux. Quatre lésions malignes ont été relevées, toutes à un stade précoce. On n'a observé aucune complication à la suite de l'examen par FS.

INTERPRÉTATION : Le rapport montre que la sigmoïdoscopie à l'aide du FS peut être pratiquée de façon sûre et efficace par du personnel non médical en milieu communautaire au Canada. Il en coûte beaucoup moins cher de faire effectuer l'examen par des endoscopistes non médicaux que par des endoscopistes médicaux spécialisés. Il s'agit là d'une démarche qui mérite d'être sérieusement envisagée dans les analyses coût-efficacité des examens de dépistage du CCR.
Tn Western countries, colorectal cancer (CRC) is one of the most common malignant diseases in men and women. It is the second major contributor to cancer mortality and the third most common incident cancer in Canada. The case-fatality rate is $50 \%(1-5)$. Most cases of CRC originate from benign adenomatous polyps (6-8) following an approximate dwell-time of 10 to 15 years $(6,8,9)$. A reduction in the incidence of cancer has been reported following polyp detection and excision (10-14), implying that CRC is a preventable disease if identified by screening at the premalignant stage.

Most of the controlled evidence favouring screening comes from studies using fecal occult blood testing (FOBT). Three frequently cited randomized FOBT trials suggest that CRC mortality reductions range from 15\% to $33 \%$ (15-18). However, this modality is plagued by sensitivity and false negative concerns, with a reported inadequacy in its capacity to detect adenomas and cancers (19).

As a result, interest has been directed at endoscopic screening, including flexible sigmoidoscopy (FS). While evidence exists to substantiate the screening role of FS in detecting and reducing the incidence and mortality of CRC $(14,20-28)$, there are few controlled data in this regard. Endoscopic screening is hampered by cost concerns and a short supply of adequately trained providers. It has been shown elsewhere that nonphysicians can provide FS as efficaciously and safely as can specialist physicians (29-35), potentially increasing availability and reducing delivery costs of the procedure.

To determine the feasibility of nonphysicians performing FS in a Canadian community setting, we report on a group of consecutively screened, average-risk patients 50 years of age and older, in whom all FS procedures were carried out by nurse-endoscopists, with video review done by specialist physicians. This is the first study of FS by nonphysician personnel in Canada and one of the few in a community setting.

\section{PATIENTS AND METHODS}

From March 1999 to March 2000, 525 patients were screened via FS in the Endoscopy Unit at Scarborough Hospital, General Site, Toronto, Ontario. Scarborough Hospital is a community-based institution serving a population of approximately 500,000 people. The protocol was reviewed by the College of Nurses of Ontario, Canadian
Medical Protective Association, Scarborough Hospital Research and Bioethics Committee, and Healthcare Insurance Reciprocal of Canada. Patients were randomly referred by their physicians following an information campaign. Five hundred forty patients were referred and given necessary instructions. Five hundred twenty-five (97.2\%) patients actually presented for screening and completed a questionnaire on details such as age, family history of CRC, personal history of CRC and relevant symptomatology. Inappropriately referred patients were excluded from the analysis phase but, nonetheless, underwent sigmoidoscopy. The referring physician was advised of the nature of the inappropriate referral in the ensuing report. The final study group comprised 488 patients. No effort was made to collect information on past FOBT screening. Preparation entailed a single phosphate enema administered 1 to $2 \mathrm{~h}$ before the procedure. No premedication or sedation was administered. All patients gave informed consent.

FS was performed using the $70 \mathrm{~cm}$ Olympus flexible video sigmoidoscope EVIS-CF 1405 (Olympus America, USA) and Sony SVO 9500 MDP videocassette recorder (Sony, USA) by two trained gastrointestinal assistants (GAs). Training included study of the anatomy and physical assessment, followed by supervised practice on a model, then live procedures with assistance. Once judged competent by the specialist physician, GAs carried out independent examinations, with approximately 50 training procedures necessary to achieve the required expertise to operate independently. All screenings were videotaped, and following a review by the supervising gastroenterologist, a report was sent to the referring physician. The identification of polypoid lesions at FS prompted a recommendation that the patient undergo colonoscopy. Some instances required a reminder to the doctor that the patient did not return for follow-up. Local regulations did not permit GAs to perform biopsies. Polyp size was estimated visually and confirmed at the time of polypectomy.

\section{RESULTS}

The average extent of FS was $52.9 \mathrm{~cm}(\mathrm{SD} \pm 12.1 \mathrm{~cm})$ (Table 1), and the mean time from insertion to removal of the instrument was $8.4 \mathrm{~min}(\mathrm{SD} \pm 3.9 \mathrm{~min})$. Five hundred forty patients were referred for screening with 525 actually presenting, giving a compliance rate of $97.2 \%$. In spite of an information brochure, some patients were inappropriately 
TABLE 1

Depth of insertion of scope and number of sigmoidoscopies inserted to each level for colorectal cancer screening

\begin{tabular}{lc}
\hline Depth $(\mathbf{c m})$ of insertion & Number of sigmoidoscopies (\%) \\
\hline$<30$ & $13(2.66 \%)$ \\
$30-40$ & $89(18.24 \%)$ \\
$41-50$ & $116(23.77 \%)$ \\
$51-60$ & $183(37.50 \%)$ \\
$61>$ & $87(17.82 \%)$ \\
\hline
\end{tabular}

referred with a family history of CRC (32) and an age of less than 50 years (5). Those patients were excluded from the analysis, which was limited to 488 appropriately referred patients. The mean age was 62.2 years $(\mathrm{SD} \pm 8.2$ years) with an age range of 50 to 86 years. There were 266 men (54.5\%). There were no complications resulting from FS.

Polyps were identified at FS in 75 patients or $15.4 \%$ of the study group. Of these, 73 (97.3\%) patients appeared for follow-up, which consisted of colonoscopy in 71 patients and repeat FS with biopsy in two patients. Of 71 colonoscopies, 69 (97.2\%) were complete to the cecum. Tissue was not obtained in one colonoscopic examination where a patient with a small polyp was inadvertently maintained on anticoagulants at the time of examination. Histology was, therefore, available in 72 patients, 68 of whom had total colonoscopy. There was one complication of colonoscopy, consisting of bleeding following hot biopsy of a hyperplastic polyp, requiring a $2 \mathrm{U}$ blood transfusion and repeat examination to achieve hemostasis endoscopically.

Forty people ( $8.2 \%$ of the group), for whom histology was available, had a total of 50 neoplastic polyps identified at FS (Table 2). A further 12 polyps were identified at colonoscopy above the extent of FS in this group. Twentytwo patients had hyperplastic polyps at FS, and in 10 patients the polyps identified at FS could not be located at colonoscopy. In these $32(6.6 \%)$ patients without neoplastic lesions within reach of the sigmoidoscope, a total of five neoplastic lesions were identified proximally at colonoscopy. One of these lesions was a carcinoma of the appendix. A total of 23 advanced neoplastic lesions (polyps containing carcinoma, at least $10 \mathrm{~mm}$ in size or with villous component) were found in 19 (3.9\%) patients. Four (0.8\%) patients had lesions containing carcinoma. None of these were more advanced than Dukes' stage A.

\section{INTERPRETATION AND DISCUSSION}

There is general agreement that screening of asymptomatic, average-risk people for CRC is beneficial. Current controversy revolves around the relative cost and effectiveness of various screening strategies, and the level of funding available. While controlled trials show a benefit from annual or biennial FOBT with follow-up colonoscopy, this strategy is beset by issues of test sensitivity, specificity and compliance with repeated testing $(15-17)$. These trials indicate that
TABLE 2 Findings at colonoscopy in the proximal colon related to
size and histology of polyps identified at flexible
sigmoidoscopy

\begin{tabular}{|c|c|c|c|c|c|c|}
\hline \multirow[b]{2}{*}{ Findings } & \multicolumn{3}{|c|}{ Sigmoidoscopy (distal) } & \multicolumn{3}{|c|}{ Colonoscopy (proximal) } \\
\hline & $\begin{array}{l}\text { Patients } \\
\text { (n) }\end{array}$ & $\begin{array}{l}\text { Number } \\
\text { of polyps }\end{array}$ & Histology & $\begin{array}{l}\text { Patients } \\
\text { (n) }\end{array}$ & $\begin{array}{l}\text { Number } \\
\text { of polyps }\end{array}$ & Histology \\
\hline \multirow[t]{3}{*}{ Non-neoplsatic } & $32^{*}$ & & & 4 & 5 & $\mathrm{TA}=3$ \\
\hline & & & & & & $\mathrm{TVA}=1$ \\
\hline & & & & & & $C A=1$ \\
\hline \multirow{2}{*}{$\begin{array}{l}1 \text { to } 9 \mathrm{~mm} \\
\quad \text { (neoplastic) }\end{array}$} & 30 & 35 & $\mathrm{TA}=28$ & 6 & 8 & $\mathrm{TA}=5$ \\
\hline & & & $\mathrm{TVA}=7$ & & & $\mathrm{TVA}=3$ \\
\hline \multirow{3}{*}{$\begin{array}{l}10 \text { mm or } \\
\text { more } \\
\text { (neoplastic) }\end{array}$} & 10 & 15 & $\mathrm{TA}=7$ & 3 & 4 & $\mathrm{TA}=4$ \\
\hline & & & $\mathrm{TVA}=5$ & & & \\
\hline & & & $\mathrm{CA}=3$ & & & \\
\hline
\end{tabular}

FOBT detects only $50.0 \%$ of CRC in patients who are tested and that the compliance rate of approximately 50.0\% with repeated testing lowers the overall detection rate to 25.0\%. Furthermore, because FOBT has a limited capacity to detect adenomatous polyps, CRC incidence in the screened population is reduced by a modest $20.0 \%$ (36).

Endoscopic approaches to CRC screening appear to be much more effective than FOBT alone, not only in cancer detection, but also in cancer prevention by the detection and removal of cancer precursors. While there are no relevant controlled studies, colonoscopic screening is accepted as the most effective strategy, with a predicted reduction in CRC incidence and mortality of $75.0 \%$ or more (37-39). However, colonoscopy has several limitations. First, compliance with colonoscopy in unsolicited populations has not been well studied. The public may well be deterred by a relatively invasive and complex procedure. Second, widespread application of screening colonoscopy requires a large number of highly trained specialist physicians and a sophisticated setting. However, the required number of skilled colonoscopists and venues are not available in this country. Third, the high front-end cost of universal colonoscopic screening may well be unacceptable to funding agencies, even if cost effectiveness appears to be favourable.

FS is predicted to have an intermediate benefit between that of FOBT and colonoscopy (37-39). Several studies, although poorly controlled, suggest a major reduction in CRC incidence and mortality in patients undergoing sigmoidoscopy, even the limited rigid examination $(20,21,27,28)$. A single, small, randomized trial reported that FS with appropriate follow-up colonoscopic polypectomy is highly protective against CRC occurrence and mortality, with 80.0\% fewer cancers and $67.0 \%$ fewer CRC-related deaths in the screened population (40).

Currently in Canada, FS is carried out exclusively by physicians, mostly specialists. While cheaper than colonoscopy, FS is relatively expensive with physician operators. Several studies from the United States, generally in academic environments, have clearly shown that nonphysi- 
cian personnel can carry out FS as effectively and accurately as specialist physicians. The extent of examination, polyp detection rates and patient acceptance have clearly not been compromised (29-35). A review of the available literature concludes that nurse-endoscopists can effectively and safely carry out FS (41).

Our program confirms that such is the case. It is the first such undertaking in Canada and suggests that the strategy is feasible in a community setting and, therefore, applicable on a widespread basis. The yield in our subjects of $0.8 \%$ for persons harbouring malignant lesions and $8.2 \%$ for the presence of any neoplastic lesion is in keeping with the rates reported elsewhere for both physician and nonphysician operators. The extent and duration of the examination are also comparable with those reported in other studies. Furthermore, the compliance rate of $97.3 \%$ with follow-up colonoscopy is excellent, indicating that our screened population is accepting of this strategy.

The rate at which colonoscopy was recommended in our program $(15.4 \%)$ is relatively high. Unfortunately, our nurse-endoscopists are not currently permitted to do biopsies. Had they been able to do so, and only patients with neoplastic polyps advised to undergo follow-up, the endoscopy rate would have been reduced by $44.0 \%$. Because our results (Table 2) and others' suggest that neoplastic lesions are found in the proximal colon less frequently when polyps identified at FS are non-neoplastic, the addition of polyp biopsy at FS will likely prove to be cost effective. It should be noted, however, that this strategy applied to our series would have resulted in overlooking one of four lesions containing malignancy. At the present time, we are applying to the appropriate regulatory bodies to permit sigmoidoscopic biopsy, stressing that forceps biopsy does not detract from the overall safety of the procedure.

There are no analyses of the cost effectiveness of various screening strategies in the Canadian setting. The price tag of the primary screening intervention is a major determinant of cost effectiveness because that intervention is applied to $100 \%$ of patients screened. In Ontario, physicians are remunerated approximately $\$ 55.00$ for FS, exclu-

\section{REFERENCES}

1. Lieberman D, Sleisenger MH. Is it time to recommend screening for colorectal cancer? Lancet 1996;348:1463-4.

2. Fletcher RH. If it works, why not do it? N Engl J Med 1998;338:1151-5.

3. Towler B, Irwig L, Glasziou P, Kewenter J, Weller D, Silagy C. A systematic review of the effects of screening for colorectal cancer using the faecal occult blood test, Hemoccult. Br Med J 1998;317:559-65.

4. Silverberg E, Lubera J. Cancer Statistics, 1988. CA Cancer J Clin 1988;38:2-22.

5. Colorectal Cancer Screening. Final Report of the Ontario Expert Panel. Sudbury: Cancer Care Ontario, 1999.

6. Ansher AF, Lewis JH, Fleisher DE, et al. Hyperplastic colonic polyps as a marker for adenomatous colonic polyps. Am J Gastroenterol 1989;85:113-7.

7. Vogelstein B, Fearon ER, Hamilton SR, et al. Genetic alterations during colorectal-tumor development. N Engl J Med 1988;319:525-32.

8. Bedenne L, Faivre J, Boutron MC, et al. Adenoma-carcinoma sequence or "de novo" carcinogenesis? Cancer 1992;69:883-8. sive of any visit or consultation charges, with an additional $\$ 20.00$ for biopsy of suspicious lesions. A nurse-endoscopist is salaried at a rate of about $\$ 30.00 / \mathrm{h}$, including benefits. At two procedures per hour and a biopsy rate of $15.0 \%$, a physician-endoscopist with a nurse assistant will cost $\$ 73.00$ per FS, whereas a nurse-endoscopist with a nurse assistant will cost $\$ 30.00$. The significant savings using nonphysicians will likely favourably affect the cost effectiveness profile of FS, particularly because there is no demonstrable loss of quality.

The relative cost of various modalities in a given jurisdiction will also bear heavily on cost effectiveness comparisons. Models from the United States and Italy, using markedly different cost bases, suggest that cost per life saved by FS and colonoscopy is about equal $(37,42)$. These models are predicated on physician-endoscopists in all instances and generally assume that the procedure takes place in a hospital setting (43). There is a great need for cost effectiveness studies in Canada to help the funding bodies determine what level of support they wish to provide for CRC screening. Our program indicates that FS can be carried out effectively by nonphysicians, thereby lowering the cost and enhancing the cost effectiveness. Furthermore, the issue of overall physician-endoscopist shortage might be overcome, as may be the question of provision of services to less populated areas, if nonphysician labour can be substituted. Also, FS, because of its excellent safety profile, can be carried out in a nonhospital setting with minimal supporting equipment. Comparisons of in-hospital and out-ofhospital costs may further lower the financial burden of providing FS on a widespread basis.

In summary, our ongoing program has shown that FS by nonphysician personnel with physician video review can form the basis for successful CRC screening in a Canadian community setting. This strategy should be included in much needed cost effectiveness models of CRC screening in this country and elsewhere.

ACKNOWLEDGEMENT: The authors express thanks to Mrs Jeannine Savoy for invaluable secretarial assistance.
9. Kozuka S, Nogaki M, Ozeki T, et al. Premalignancy of the mucosal polyp in the large intestine: estimations of the periods required for malignant transformation of mucosal polyp. Dis Colon Rectum 1975; 18:494-500.

10. Winawer SJ, Zauber AG, Ho MN, et al. Prevention of colorectal cancer by polypectomy. N Engl J Med 1993;329:1977-81.

11. Gilbertsen VA. Proctosigmoidoscopy and polypectomy in reducing the incidence of rectal cancer. Cancer 1974;34:936-9.

12. Sampliner RE, Garewal HS. Endoscopic polypectomy reduces mortality from colorectal cancer. Arch Intern Med 1995; 155:1711-2.

13. Gilbertsen VA, Nelms JM. The prevention of invasive cancer of the rectum. Cancer 1978;41:1137-9.

14. Selby JV, Friedman GD, Quesenberry CP, Weiss NS. A case-control study of screening sigmoidoscopy and mortality from colorectal cancer. N Engl J Med 1992;326:653-7.

15. Mandel JS, Bond JH, Church TR, et al. Reducing mortality from colorectal cancer by screening for faecal occult blood. N Engl J Med 1993;328:1365-71. 
16. Hardcastle JD, Chamberlain JO, Robinson MHE, et al. Randomized controlled trial of faecal-occult-blood screening for colorectal cancer. Lancet 1996;348:1472-7.

17. Kronborg O, Fenger C, Olsen J, Jorgensen OD, Sandergaard O. Randomized study of screening for colorectal cancer with faecaloccult blood test. Lancet 1996;348:1467-71.

18. Winawer SJ, Andrews M, Flehinger B, et al. Progress report on controlled trial of fecal occult blood testing for the detection of colorectal cancer. Cancer 1980;45:2959-64.

19. Macrae FA, St John DJB. Relationship between patterns of bleeding and haemoccult sensitivity in patients with colorectal cancer or adenomas. Gastroenterology 1982;82:891-8.

20. Newcomb PA, Norfleet RG, Stoner BE, et al. Screening sigmoidoscopy and colorectal cancer mortality. J Natl Cancer Inst 1992;84:1572-5.

21. Atkin WS, Morson BC, Cuzick J. Long-term risk of colorectal cancer after excision of rectosigmoid adenomas. N Engl J Med 1992;326:658-62.

22. Wherry DC, Thomas WM. The yield of flexible fiberoptic sigmoidoscopy in the detection of asymptomatic colorectal neoplasia. Surg Endosc 1994;8:393-5.

23. Shida H, Yamamoto T. Fiberoptic sigmoidoscopy as the first screening procedure for colorectal neoplasms in an asymptomatic population. Dis Colon Rectum 1989;32:404-5.

24. Gupta TP, Jaszewski R, Luk GD. Efficacy of screening flexible sigmoidoscopy for colorectal neoplasia in asymptomatic subjects. Am J Med 1989;86:547-50.

25. Matter SE, Campbell DR. Significance of distal polyps detected with flexible sigmoidoscopy in asymptomatic patients. Arch Intern Med 1992;152:1776-80.

26. Krevsky B, Niewiarowski T, League R, Herman H, Matz L, Fisher RS. Flexible sigmoidoscopy screening in an industrial setting. Am J Gastroenterol 1992;87:1759-62.

27. Muller AD, Sonnenberg A. Protection by endoscopy against death from colorectal cancer. Arch Intern Med 1995;155:1741-8.

28. Selby JV, Friedman GD. US Preventive Services Task Force. Sigmoidoscopy in the periodic health examination of asymptomatic adults. JAMA 1989;261:595-601.

29. Maule WF. Screening for colorectal cancer by nurse endoscopists. N Engl J Med 1994;330:183-7.

30. Rosevelt J, Frankl H. Colorectal cancer screening by nurse practitioner using $60-\mathrm{cm}$ flexible fiberoptic sigmoidoscope. Dig Dis Sci 1984;29:161-3.

31. Schroy PC, Wiggins T, Winawer SJ, Diaz B, Lightdale CJ. Video endoscopy by nurse practitioners: a model for colorectal cancer screening. Gastrointest Endosc 1988;34:390-4.

32. Shapiro M. Colorectal cancer screening by paramedical personnel. Dig Dis Sci 1984;29:159-60.

33. Schoenfeld PS, Cash B, Kita J, Piorkowski M, Cruess D, Ransohoff D. Effectiveness and patient satisfaction with screening flexible sigmoidoscopy by registered nurses. Gastrointest Endosc 1999;49:158-62.

34. Wallace MB, Kemp JA, Meyer F, et al. Screening for colorectal cancer with flexible sigmoidoscopy by nonphysician endoscopists. Am J Med 1999;107:214-8.

35. Schoenfeld P, Lipscomb S, Crook J, et al. Accuracy of polyp detection by gastroenterologists and nurse endoscopists during flexible sigmoidoscopy: a randomized trial. Gastroenterology 1999;117:312-8

36. Mandel JS, Church TR, Bond JH, et al. The effect of fecal occultblood screening on the incidence of colorectal cancer. N Engl J Med 2000;343:1603-7.

37. Liberman DA. Cost-effectiveness model for colon cancer screening. Gastroenterology 1995;109:1781-90.

38. Sonnenberg A, Delco F, Inadomi JM. Cost-effectiveness of colonoscopy in screening for colorectal cancer. Ann Intern Med 2000;133:573-84.

39. Frazier AL, Colditz GA, Fuchs CS, Kuntz KM. Cost-effectiveness of screening for colorectal cancer in the general population. JAMA 2000;284:1954-61

40. Thiis-Evensen E, Hoff GS, Sauar J, Langmark F, Majak M, Vatn MH. Population-based surveillance by colonoscopy: Effect on the incidence of colorectal cancer. Telemark Polyp Study 1. Scand J Gastroenterol 1999;4:414-20.

41. Schoenfeld P, Piorkowski M, Allaire J, Ernst R, Holmes L. Flexible sigmoidoscopy by nurses: state of the art 1999. Gastroenterol Nurs 1999;22:254-61.

42. Sorrentino D, Paduano R, Bernardis V, Piccolo A, Bartoli E. Colorectal cancer screening in Italy: feasibility and cost-effectiveness in a model area. Eur J Gastroenterol Hepatol 1999;11:655-60.

43. Lewis JD. Prevention and treatment of colorectal cancer: Pay now or pay later. Ann Intern Med 2000;133:647-9. 


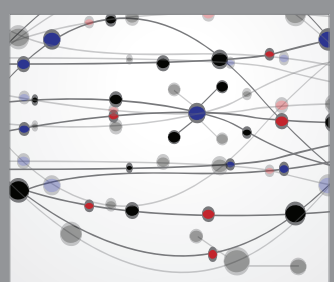

The Scientific World Journal
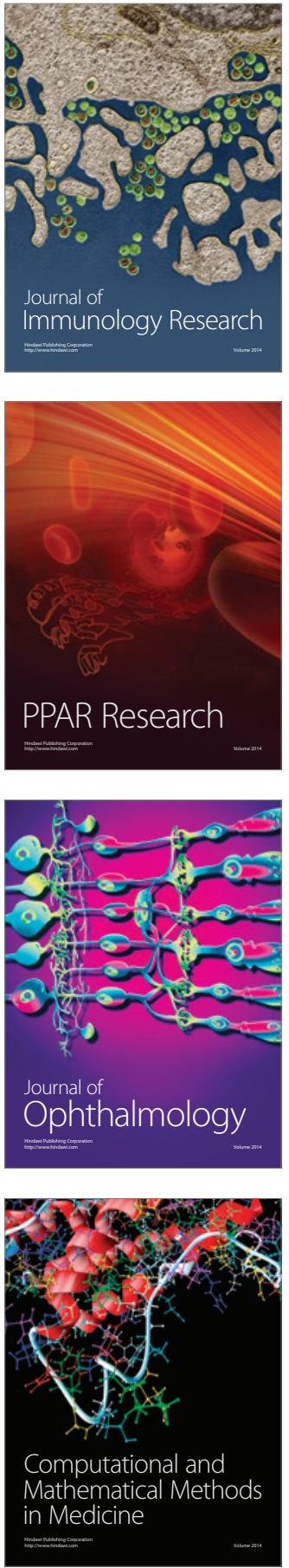

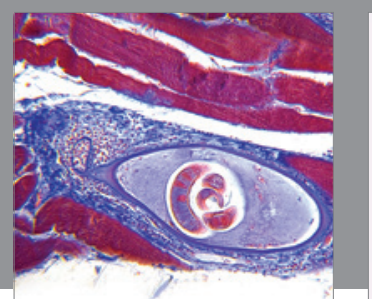

Gastroenterology Research and Practice

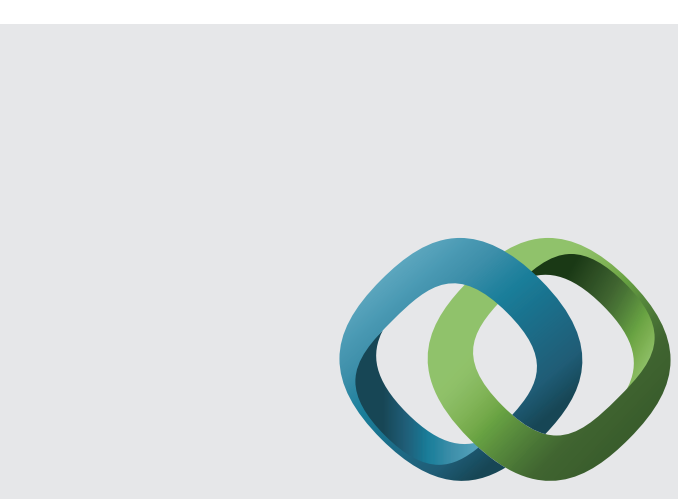

\section{Hindawi}

Submit your manuscripts at

http://www.hindawi.com
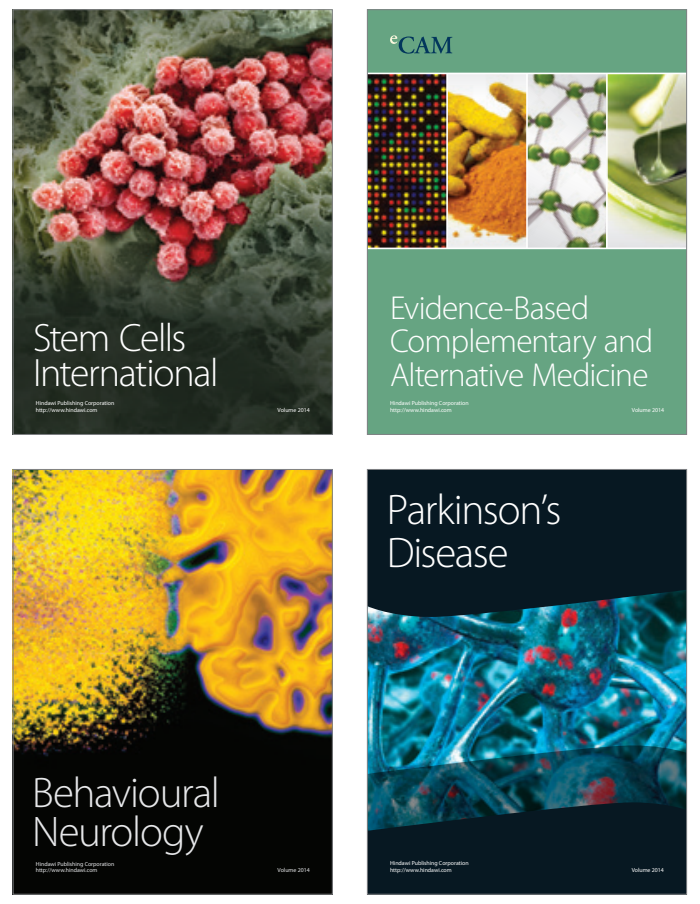
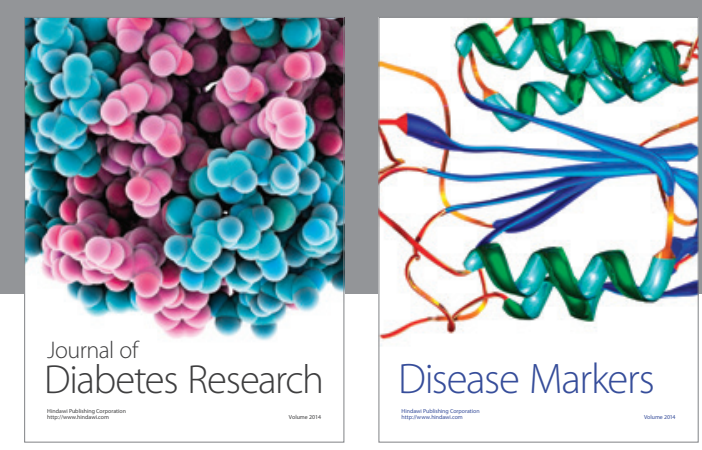

Disease Markers
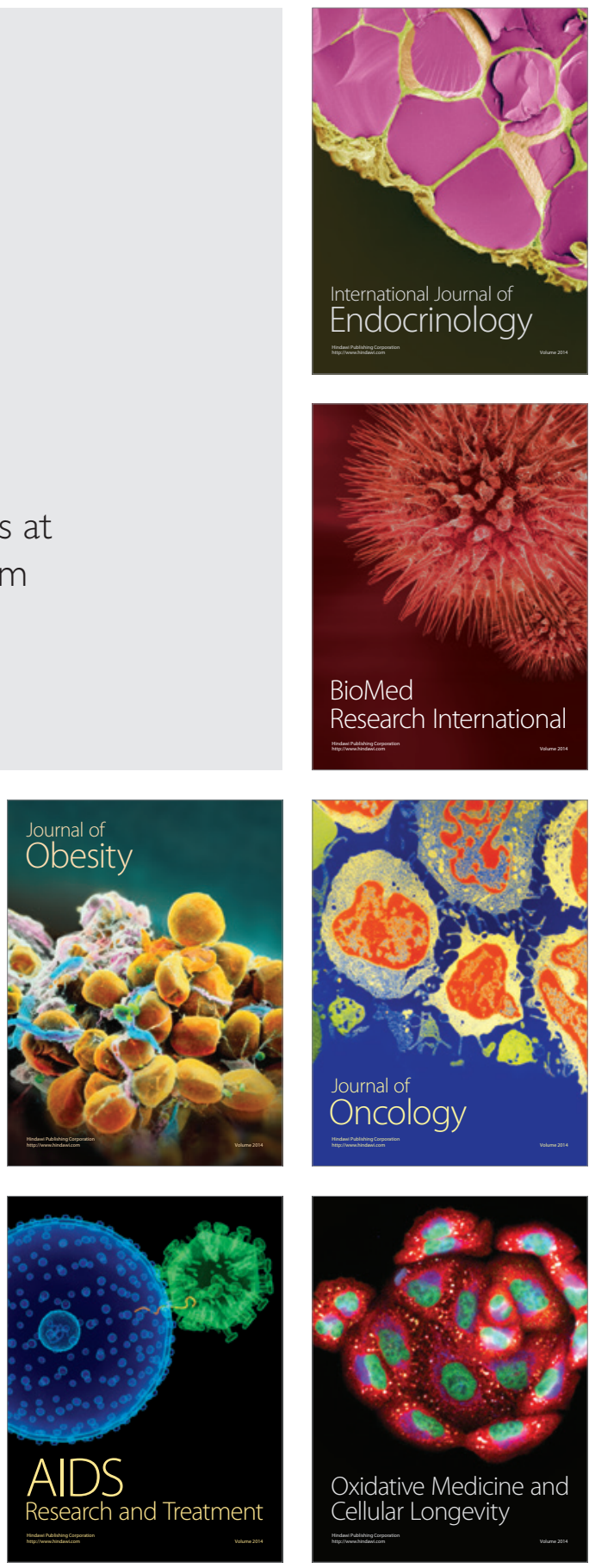